\title{
Lumen
}

Selected Proceedings from the Canadian Society for Eighteenth-Century Studies

Travaux choisis de la Société canadienne d'étude du dix-huitième siècle

\section{The Mirror and Manners: Watching, Being Watched, and Watching Oneself in Rococo Spaces}

\section{Rosemary Legge}

Volume 37, 2018

URI : https://id.erudit.org/iderudit/1042225ar

DOI : https://doi.org/10.7202/1042225ar

Aller au sommaire du numéro

Éditeur(s)

Canadian Society for Eighteenth-Century Studies / Société canadienne d'étude du dix-huitième siècle

ISSN

1209-3696 (imprimé)

1927-8284 (numérique)

Découvrir la revue

Citer cet article

Legge, R. (2018). The Mirror and Manners: Watching, Being Watched, and

Watching Oneself in Rococo Spaces. Lumen, 37, 91-105.

https://doi.org/10.7202/1042225ar 


\title{
The Mirror and Manners: Watching, Being Watched, and Watching Oneself in Rococo Spaces
}

\author{
Rosemary LEGGE \\ Queen's University
}

In Jean-Antoine Watteau's painting L'Enseigne de Gersaint (1720) [figure 1], the artist presents a scene of a marchand-mercier's shop, specifically that of the art-dealer Edme-François Gersaint. Gersaint's boutique, in the heart of Paris, was a primary site for the consumption of art and luxury objects by the aristocracy at the beginning of the eighteenth century. Watteau's painting depicts refined men in powdered wigs and beautiful women in shimmering silks engaging with each other and with the goods for sale. While initially all of the frames hanging on the walls of the expansive room appear to enclose paintings, upon closer inspection the viewer can identify at least four mirrors in the image. Of particular interest is that, in this shop filled with large dazzling oil paintings of mythological and religious scenes, the object that captures the attention of three of the shop's patrons is a small toilette mirror seen on the far right. The mirror is accompanied by other parts of its set: brushes, boxes, and bottles, all finished with a black lacquer, showing contemporary interest in new and exotic materials. ${ }^{1}$

1. This lacquer-work was a part of the chinoiserie craze in eighteenth-century interior décor. For the significance and ascendancy of 'Eastern' influence in "culturally embedded objects" of the eighteenth-century European interior, see David L. Porter, "Monstrous Beauty: Eighteenth Century Fashion and the Aesthetics of the Chinese Taste," Eighteenth-Century Studies 35.3 (2002): 395-411. For an analysis of the wonder of the new materials and production techniques used to create matching sets, see Mimi Hellman "The Joy of Sets: The Uses of Seriality in the French 
These three figures are looking at a mirror's reflection, which makes their gazes mysterious: is the woman on the right admiring her own image in the mirror, or is she seeing something else within it? Are her male companions looking at themselves, each other, or the woman? As Watteau only depicts back of the mirror, the viewer cannot quite discern at what or whom, these three are looking. What Watteau does make apparent in this scene is the status of the mirror in the earlyeighteenth century. At art shops like Gersaint's, mirrors were sold alongside the "fine art" of painting. In this image, Watteau may be suggesting that these aristocratic shoppers are more interested in admiring their own reflections in the mirror than appreciating the academic paintings that surround them. ${ }^{2}$

After a number of technological advances in glass production in the late-seventeenth century, mirrors, such as those sold by Gersaint, proliferated in the domestic spaces of the elite in eighteenth-century France. Beginning in the court of Versailles, and quickly spreading to the hotels particuliers of the aristocracy in Paris, the mirror became a key feature of the fashionable goût moderne (rococo) in interior decoration. The mirror became ubiquitous in aristocratic and bourgeois homes, taking the place of paintings and tapestries at eye-level, mimicking windows, and enhancing chimney mantles. The expensive and fragile glass mirror was a gleaming symbol of affluence and opulence for the French elite.

Architects and designers were fascinated with the mirror's ability to create delightful effects of shine, glitter, and illusion. However enchanting, the mirror's reflective effects also enabled exhibitionism, voyeurism, and vanity. The mirror gave its owner the unprecedented ability to examine her or himself at full length, resulting in a new visual consciousness of the body and a new standard of self-control. Mirrors

Interior," In Furnishing the Eighteenth Century: What Furniture Can Tell Us about the European and American Past, ed. Dena Goodman and Kathryn Norberg, (New York and Oxon: Taylor \& Francis, 2007): 129-54.

2. This idea of the mirror displacing the painting was also a topic of criticism of the time, such as in Étienne La Font de Saint-Yenne, Reflexions Sur Quelques Causes de L'état Présent de La Peinture En France Avec Un Examen Des Principaux Ouvrages Exposés Au Louvre Le Mois d'Août 1746, ed. Jean Neaulme A La Haye (Paris: 1747). A translation of Saint-Yenne's critique of the mirror can be found in Katie Scott, The Rococo Interior, Decoration and Social Spaces in Early Eighteenth-Century Paris (New Haven and London: Yale University Press, 1995), 254. 
provided a way for the French elite, a group preoccupied with decorum, to monitor each other's, as well as their own, manners. In this paper, I first situate the origins of the rococo mirror in the history of interior decoration. I then consider some of the social ramifications of mirrors in the private and semi-private domestic spaces of eighteenthcentury France, by exploring its use in the surveillance and maintenance of behaviour for the French elite. I argue that the rococo mirror was an effective tool for the careful construction, practice, and performance of elite identities at a moment when these identities were increasingly contested and precarious.

The rococo mirror has roots in the baroque decorative style of Versailles under Louis XIV. The new methods of mirror production can also be traced to the Sun King's policies; Louis' investment in establishing a viable mirror production company in France ultimately led to the creation of the French flat-mold technique as an alternative to the Venetian blown-glass method. ${ }^{3}$ In 1684, Louis' Hall of Mirrors at Versailles was finally complete, a technological and architectural feat designed by Jules Hardouin-Mansart, composed entirely of mirrors made in Normandy and assembled in Paris. Though decorative mirrors had existed before, nothing to this extent and scale had been achievable due to costs and production challenges.

For seventeenth-century audiences, the effect of Louis' galerie was nothing short of miraculous. One monthly gazette pronounced that the vision of the hall was so stunning that to attempt a description risked "weakening the beauties which one seeks to bring to light." ${ }^{\prime \prime}$ Felipe Chaimovich argues that the Hall of Mirrors is a perfect example of the Sun King's harnessing of visual display to assert his absolute power. According to Chaimovich, the mirrors of Versailles were a direct means of social control through visual surveillance, effectively enforcing the rigid class structure of the baroque French court. Chaimovich argues that the way mirrors were framed and presented

3. For a thorough report of the scientific, economic, and political conditions that brought about the French flat-mold mirror and for the early history of the SaintGobain mirror manufactory, see "Chapter 2: The Royal Glass and Mirror Company" in Sabine Melchior-Bonnet, The Mirror: A History (New York: Routledge, 2001), $35-69$.

4. Mercure Galant (Paris: December 1682), 102. Translation by author. Parts of the Mercure Galant's description of the Hall of Mirrors also quoted in MelchiorBonnet, The Mirror: A History, 47. 
alongside paintings that emphasized compositional hierarchy invited those reflected to be reminded of their own position and to feel the ever-watchful eyes of the Sun King. ${ }^{5}$ For Chaimovich, these origins of the French manufactured mirror demonstrate not only an interest in aesthetics but also the concerted efforts by the State to control the aristocracy through visual surveillance.

After Louis XIV's death, the Régent duc D'Orleans governed on behalf of the young Louis XV from the Palais-Royal in Paris. As French aristocrats left Versailles and "fled" to the city, they built a number of new dwellings in the latest decorative fashion, which suited a different lifestyle and domestic ideology. These hotel particuliers were built with smaller and more intimate rooms, including areas reserved for private and semi-private functions. ${ }^{6}$ Space and objects were organized to facilitate comfort (relative to Versailles) and the appearance of leisure. Many of the decorative elements of grand royal palaces, like heavy gold gilding and dark dramatic wall paintings, were transformed into the glimmering and carefree rococo. The mirror became a key element of the new style; in each room there would be at least one mirror above the fireplace. If the patron could afford it, there would be mirrors on every wall, impeccably incorporated into the boiseries (wood paneling). Mirrors were not an after-thought; they were integral to architects' designs for interiors and were framed by the same swirling and gilded forms as paintings. ${ }^{8}$ In his 1725 book chronicling the most remarkable

5. Felipe Chaimovich, "Mirrors of Society: Versailles and the Use of Flat Reflected Images," Visual Resources 24, no.4 (2008), 363.

6. Joan DeJean,"A New Interiority: The Architecture of Private EighteenthCentury Paris," In Paris: Life \& Luxury in the Eighteenth Century, ed. Charissa Bremer-David (Los Angeles: Getty Publications, 2011), 33-51.

7. DeJean writes about how the new division of space and distribution of rooms found in the hotels particuliers of early-eighteenth century Paris show an interest in display, comfort, and the display of comfort (ibid). She specifically connects the privacy of small rooms and the comfort and they provided their inhabitants to social station by quoting the Mercure de France's proclamation that "those of the highest rank live in the smallest rooms" (41). Also see DeJean, The Age of Comfort (New York: Bloomsbury, 2009). Mimi Hellman argues that rococo furniture and was intended to make its sitters appear comfortable and at ease in "Furniture, Sociability, and the Work of Leisure in Eighteenth-Century France," Eighteenth-Century Studies 32, no. 4 (Summer 1999), 421.

8. Gauvin Alexander Bailey explains the importance of the cheminée, which was almost always topped with a mirror, in The Spiritual Rococo: Decor and Divinity from the Salons of Paris to the Missions of Patagonia (Farnham: Ashgate Publishing 
sites of Paris, Germain Brice describes how all the finest Parisian homes now have mirrors so large that they reach up to rooms' cornices and how these create wondrous visual effects. He describes the mirrors in one Salon:

The mirrors, which occupy the place above the magnificent chimneys... are of an extraordinary grandeur. They are framed by a curved border, enriched with various artful and inventive ornaments. These mirrors, placed advantageously, create a happy effect, repeating the beauties of this place...?

These beautiful rooms became sites of dispersed power as the salons of many hotels became spaces for cultural, political, and intellectual conversations and the dissemination of new ideas between members of the French elite, both those born noble and the "newly rich." ${ }^{10}$ The rococo style was not only a style of the old aristocracy; those in Paris making their fortunes in the commercial sphere and the financial sector also decorated lavish homes with similar décor. ${ }^{11}$ For those who could not afford the hand-carved boiseries, gilded furniture, and crystalline mirrors; the depictions of the style were also widely circulated in print. Architectural manuals and guidebooks with intricate engravings of plans for rococo interiors and catalogues of objects became popular as items of visual interest on their own terms. ${ }^{12}$

Limited, 2014). Bailey compares the rococo cheminée to the "column/capital/entablature unit in a Classical Order." The design for the cheminée "serves as a blueprint for the stylistic mode of the entire room" (64).

9. Germain Brice, Nouvelle description de la ville de Paris, et de tout ce qu'elle contient de plus remarquable, première tome, 8th edition, ed. Julien-Michel Gandouin and Francois Fournier (Paris, 1725), 244. Translation by author.

10. Leora Auslander, Taste and Power: Furnishing Modern France (Berkeley and Los Angeles: University of California Press, 1996), 50.

11. The role of financiers in the development of the early eighteenth-century domestic design is outlined by Rochelle Ziskin in The Place Vendôme: Architecture and Social Mobility in Eighteenth-Century Paris (Cambridge: Cambridge University Press, 1999): 1-2. Ziskin argues that the new style of French interior décor emerged "from the specific nature of French society, with its hierarchy of social estates and ranks, and from the representational, ceremonial, and functional needs of its elites" (2). However, Ziskin seeks to distinguish between these elites, and she sees the financiers particularly significant due to their unparalleled "social mobility." Financiers were able to purchase noble titles, yet were often still perceived as bourgeois by those above and below in the social hierarchy (2).

12. Meredith Martin, "The Ascendancy of the Interior in Eighteenth-Century Architectural Theory," in Architectural Space in Eighteenth-Century Europe: Con- 
While the aristocracy in Paris enjoyed new freedom from the unyielding rules of the court of Versailles, their social position was increasingly insecure. As Katie Scott explains, while the nobility of France was once associated with the vocation of military service, by the eighteenth century class had become an attribute of birth, an inherited state-of-being rather than state-of-doing. ${ }^{13}$ Beyond the growing slippage between the traditional roles within the aristocracy, nobles had to contend with the Crown making aristocratic titles purchasable by those not born noble-most notably financiers. ${ }^{14}$ Further, even though the French nobility of the early-eighteenth century had the highest social status apart from royalty, they were obligated to keep up appearances, even if they could not afford the extravagant consumption of luxury goods. ${ }^{15}$ The nobility in Paris thus distinguished their rank by a multitude of symbols that represented the supposedly "natural" qualities of nobility. Many of these were material, like the objects and surfaces of the interior: tasteful porcelains, refined wall paintings, and delightful furniture. However, since the nobility could not control access to these material goods, there was fear that the objects could lose their meaning. ${ }^{16}$ While many of the rules governing social hierarchy benefitted the Second Estate, laws discouraged members of the nobility to increase their wealth through commercial activity. ${ }^{17}$ Leora Auslander and other scholars have looked at the material consumption of the aristocracy in this time in terms of somewhat desperate attempt to maintain power and status and have seen the bourgeoisie's consumption practices as a means of advancing social position. Similarly, items of dress and cosmetics, some of which were restricted by sumptuary laws, can be interpreted as reflecting the status and group identity of

structing Identities and Interiors, edited by Martin and Denise Amy Baxter (Farnham and Burlington: Ashgate Publishing Limited, 2010), 15.

13. Scott, The Rococo Interior, 85 .

14. Auslander, Taste and Power: Furnishing Modern France, 49.

15. Scott, The Rococo Interior, 86.

16. Nobert Elias, The Court Society, translated by Edmund Jephcott (Dublin: University College Dublin Press, 2006), 73.

17. France under the ancien régime was legally divided into three estates, not including the monarch: the First Estate (clergy), the Second Estate (nobility) and the Third Estate (commoners). 
the wearer. ${ }^{18}$ And yet, as with interior décor, wealthy non-nobles continuously adopted the newest aristocratic fashions. ${ }^{19}$

Whereas the rush to accumulate luxury goods was perhaps an easier game for financiers or the bourgeoisie to play, the older aristocracy still had the advantage of differentiation through courtesy rituals and the experience of court etiquette. These subtle visual and behavioral aspects of class - the movements of the body, the art of conversation, and the ability to be always pleasing to others-are harder for the art historian to assess. It may seem as though these features of elite identity are separate from the items of luxurious decoration filling the chambres and salons of the hôtels particuliers. However, certain scholars of the rococo have considered the items and spaces of the interior on an ancillary level: as objects and settings that shape and mediate the body and its movements to adhere to the physical standards of elite identity and to visually amplify the successful performance of what Mimi Hellman calls the "work of leisure." ${ }^{20}$ The mirror operated in relation to power and status on these two levels. The large, expensive, and aesthetically pleasing mirror was certainly a symbol of wealth and opulence, but it also acted as a means by which to control, moderate, and augment the appearance of one's social condition through careful regulation of the body and its movements. The mirror, a material marker of excess, literally reflected these immaterial elements of coded behaviour and interaction.

In order to understand the image of civility and manners that these mirrors reflected back to their viewers, it is important to understand the particulars of how they were installed. The rococo decorative style, while associated with playfulness and freedom, was not without rules. Architects such as Germain Boffrand and Augustin-Charles d'Aviler provided guidelines to create harmonious and appropriate decorative

18. In The Rococo Interior, Katie Scott explains how Nicolas Delamare's Traite de la police (1705-38) reflects that the legal constraints on consumption were not "aggressive" but were "defensive" - meaning that those seventeenth-century laws "protected the perceptual boundaries of rank" rather than actively enforcing appropriate consumption (81).

19. Kimberly Chrisman-Campbell, "Dressing to Impress: The Morning Toilette and the Fabrication of Femininity," in Paris: Life \& Luxury in the Eighteenth Century, ed. Charissa Bremer-David, (Los Angeles: Getty Publications, 2011), 53-74.

20. Mimi Hellman, "Furniture, Sociability, and the Work of Leisure in EighteenthCentury France," 433. 
themes in the interior. Thus, architectural treatises can shed light on the technical direction of applying decoration, as well as on ideals of elegance, taste, and propriety. In these texts, glass and mirrors are discussed at length: where they should be installed, how the frame should relate to the ornamentation of the room, and the aesthetic benefits of their reflective quality. In his Book of Architecture from 1745, Boffrand describes how mirrors have the potential to enhance the light and beauty of a space but also takes note of the emphasis they put on the image of the body. For example, he advises that lights be placed not too far above one's height when standing, as higher mirrors would present women with an unflattering reflection:

Well placed, looking-glasses are a great ornament to an apartment. This is so, most of all, when they reflect light from outside and a pleasing view; when their size is proportionate to that of the room, when their height is proportionate to their width, and when they are hung opposite to each other, thus lengthening the enfilade and reflecting the lights in different ways. Such lights are not to be placed more than six feet from the floor, or they would give a bruised and hollow look to the eyes, and this the ladies would never forgive. ${ }^{21}$

For architects and designers such as Boffrand, even though the mirror needed to be carefully placed in order to prevent unappealing reflections, its capacity to reflect a clear vision of whatever lay in front of it was still considered one of its primary virtues. In Augustin-Charles d'Aviler's architectural treatise published in 1738 , he informs readers us that mirrors were to be flat, without any cracks or curves, and the glass should be free from bubbles or discoloration. All of these provisions point to an interest in the mirror's power to reflect human vision as authentically as possible. As d'Avilier explains, "one must have great care to ensure that the seam of the first glass is above the height of the tallest man; since nothing is more displeasing than to see ones fractured face looking back at himself in the mirror." 22 Thus, as Boffrand similarly suggests, it is best that mirrors present a flattering vision of

21. Germain Boffrand, Book of Architecture Containing the General Principles of the Art and the Plans, Elevations and Sections of Some of the Edifices Built in France and Foreign Countries, ed. Caroline van Eck, trans. David Britt, (Aldershot: Ashgate Publishing Limited, 2002), 16.

22. Augustin-Charles d'Aviler, Cours d'Architecture: qui comprend les ordres de Vignole, avec des commentaires, les figures $\&$ les descriptions de ses plus beaux bâti- 
the self and the space. D'Aviler's caution against too-low glass-seams also implies that the mirror should faithfully present visual reality when it comes to personal appearance.

The mirror's ability to reflect what the eye sees is also the central conceit of a late-seventeenth-century tale by Charles Perrault. In the story, Cupid transforms a portrait painter, Orante, into flat mirror. Orante's fateful flaw was portraying the imperfections of his sitters too faithfully; ergo, the mirror was the object that most aligned with his qualities. Orante learns the lesson that the role of a portrait is not to reflect reality absolutely, like a mirror, but to capture a flattering likeness. ${ }^{23}$ The story demonstrates how the author expected people to see mirrors at the time. Mirrors were cold and objective, trustworthy tools that could reveal what a perceptive man like Orante might see while looking at someone. These examples all point to the mirror existing in a somewhat perilous relationship to its viewer; although one could take pleasure in the magic of reflection, the mirror also made one subject to the truth of one's appearance and behaviour.

Appearance and behaviour were a great concern to those members of the elite who lined their hôtels with mirrors. As I noted above, elite identity was bound to the successful performance of politesse. As a good mirror was to appear seamless, good manners could not show any sign of defect. Conduct and etiquette books for the nobility, increasingly popular at the time, can illuminate what eighteenth-century eyes might have been checking in the mirror. In one of the most widely circulated examples of the genre, Antoine de Courtin's treatises on Civilité present a long list of words, actions, and habits inexcusable in polite society. Courtin advised his noble reader that it is "unbecoming to make faces, to rowl [sic] your tongue in your mouth, to bite your lips, to play with your locks, to wink with your eyes, to rub your hands, crack your fingers, scratch your head, or shrug your shoulders." ${ }^{24}$ Courtin saw

mens... Géneralement tout ce qui regarde l'art de bastir, (Paris: Chez Jean Mariette, 1738), 189, Translation by Author.

23. Allen S. Weiss retells Perrault's story Le miroir ou la métamorphose d'Orante in Mirrors of Infinity: The French Formal Garden and 17th-Century Metaphysics, (New York: Princeton Architectural Press, 1995), 84.

24. This quotation is from an eighteenth-century English edition of the treaty. The original was originally published in 1671 , in French. Antoine de Courtin, Rules of Civility and Genteel Behaviour or Ways of Deportment Observed in France, among All Persons of Quality, upon Several Occasions (London, 1703), 44. 
habits as a means to reflect one's "natural" status. The control of bodily functions, he asserted, is a fundamental part of modesty and decorum, imperative in reflecting inner grace and good breeding. ${ }^{25}$ Courtin did accept that some beastly behaviours might be unavoidable, but argued that the careful observation and control of words and actions is the social and moral duty of every well-born man. ${ }^{26}$

Not only were certain behaviours frowned upon but also every movement made by a man or woman of a high station was to be elegant and refined. Above all, the body and its actions were to be as pleasing as the interior that set the stage for this display of good manners. ${ }^{27}$ Courtin describes the importance of embodying an understated grace while entering a room, as that is the moment when one attracts the most attention. ${ }^{28} \mathrm{He}$ directs that one tread softly so as not to disrupt conversation. He further prescribes the proper way to comport oneself as to ensure comfort and pleasure for all. According to Courtin, one should exhibit a "modest step, not striking the floor or the ground, not dragging one's feet... but restraining oneself and walking gently, without turning one's gaze here and there." ${ }^{29}$ Courtin also directs his noble audience to be attentive to the actions of others, as it was possible for the non-noble to observe and copy behaviour. He dedicates a chapter to the development of discernment, which, as Brett Davetian describes, is "the ability to see through the masks of others and determine their characters and motives." "30 Given that the rococo salons of these hotels particuliers were sites of social intermingling between members of the elite from various noble and non-noble origins, we can imagine the confusing relationship of glances swirling around the room: some

25. Ibid., 10-11.

26. Ibid., 1.

27. Sarah R. Cohen has connected the graceful movements of the aristocratic body in early eighteenth century to the court ballet of the late seventeenth century. Cohen posits that moving the body in the mode of the minuet or other courtly dances signaled a noble background, and that these postures were self-conscious attempts at both differentiation and community building. Sarah R. Cohen, "Un Bal Continuel: Watteau's Cythera Paintings and Aristocratic Dancing in the 1710s," Art History 17, no. 2 (1994): 164 .

28. Antoine de Courtin, Nouveau traité de la civilité qui se pratique en France parmi les honnestes gens (Paris: chez L. Josse et C. Robustel, 1712): 51.

29. Ibid., 52.

30. Brett Davetian, Civility: A Cultural History (Toronto, Buffalo, London: University of Toronto Press, 2009), 111. 
watching behaviour in order to imitate it, others watching behaviour in order to discern authenticity, and all likely watching themselves perform this dance of perception.

Our twenty-first-century eyes are now familiar with the mirror as a tool for surveillance, common in convenience stores and supermarkets, and it may seem like an anachronistic project to apply this somewhat sinister reading to the ornate mirrors of sumptuous rococo interiors. However, there is evidence of mirrors contemporary to those in eighteenth-century France being used more deliberately as a tool for spying on others, like the gossip-mirrors or street-mirrors of Early Modern Finland and Sweden. ${ }^{31}$ While I do not think that surveillance was the primary function of rococo mirrors, we can surmise by the detail of installation that these could have been important tools for the scrutiny and maintenance of properly pleasing behaviour. In salons and chambres du parade like those in the Hôtel de Roquelaure, large mirrors line opposing walls, facilitating surreptitious looking at the self and at others. In places designed for social interaction, sometimes mirrors would surround the room's inhabitants, allowing a full visual survey of the self and others from multiple angles. For oval salons, like the Salon de la Princesse at the Hôtel de Soubise [figure 2], the slightly obtuse angles of the mirrors mean that in certain positions, one could truly see oneself as others would, without even meeting one's own gaze. The mirrors lining formal rooms intended for public display and social interactions thus allowed viewers to monitor their behaviour. Visual feedback of one's appearance was readily available with a fleeting glance.

We do have some textual evidence of the eighteenth-century mirror being used to construct and monitor appearances, with the intent of presenting the appropriate identity for one's status or social condition. In a conduct book for girls published in 1749 , we see an example of the way the semi-private mirror of the toilette was used for the

31. Ylimaunu Timo, et al., "Street Mirrors, Surveillance, and Urban Communities in Early Modern Finland," Journal of Material Culture 19, no. 2 (2014), 145-67. These mirrors were installed in a perpendicular configuration in windows in early modern Finnish towns such as Kokkola and Raahe-so that while peering out a window from inside one's home, one could see others on the street below, and even around the corner. Ylimaunu et al. argue that these mirrors were "an indication of horizontal communal control," meaning that neighbours would monitor each other's behaviour, effectively using visual surveillance as form of social control. 
practice of public politeness. In one passage, the author, Madeleine de Puisieux, describes herself in front of a mirror while practicing her Italian. She explains that through careful studying of her reflected gestures and faces, she came to realize she was making herself look "strongly ridiculous." She decided that her Italian was not at all pleasing, and resolved that playing the harpsichord looked much more elegant from her view of herself in the mirror. She expresses her thoughts in the moment, "Ah! I say, this is what suits me; here is the occupation of a young person." 32 De Puisieux claims that the second activity suited her better, that she saw herself as most representative of herself while playing the harpsichord. It is important here to note that for eighteenth-century minds, the authentic self is not the same self we might imagine today. We may understand the self as a distillation of particular characteristics that are deep and unchanging, but at the time of De Puisieux, the self was largely understood as the appropriate representation of one's position or group identity. ${ }^{33}$ Authenticity was not an element of inner personal depth but a surface presentation of one's social status, gender, or nationality.

This idea of the self as a more surface representation, that how one looks and acts is an equivalence to who one is, makes the role of the mirror all the more vital in this display of manners. As Davetian argues about the Chevalier de Mérés writings on civility, "the concept of bienséance (pleasantness) was now used to reintroduce aesthetics into behaviour." ${ }^{4}$ These "behavioural aesthetics" are the key to social identity for the French elite. Davetian takes great interest in de Méré's use of the term vraisemblance. He argues that vraisemblance "was an attempt to create mutual resemblance through the practice of a conservational ethic that created mutual identification and pleasure." He goes on:

The word [vraisemblance] itself needs be understood as a derivative as vrai (real) and semblance (appearance or semblance). Vraisemblance means to give the appearance of being real through whatever dramatur-

32. Author's translation of "Ah! dis-je, c'est-la ce qui me covient." Madeleine de Puisieux, Conseils à Une Amie (Frankfurt and Mainz: Chez Francois Varrentrapp, 1750), 27-28.

33. Dror Wahrman, The Making of the Modern Self: Identity and Culture in Eighteenth Century England (New Haven and London: Yale University Press, 2004), 168 .

34. Davetian, Civility: A Cultural History, 112. 
gical means are available. While it represents reality, it alters it through harmonizing and refining it according to existing social protocols. It requires forethought and the ability to express oneself as naturally as possible. It is the artifice of non-artifice - a practiced naturalness. ${ }^{35}$

Davetian does not refer to mirrors, yet it is evident that the mirror is perhaps the best "dramaturgical" device for the practice and performance of appearing real, beyond its metaphorical relationship to the term vraisemblance. ${ }^{36}$ However, the mirror was likely not just the stage set or a passive prop in this theatre of manners. The mirror was also an actor, altering the reality of the room and perhaps the psychology of its viewers.

Sabine Melchior-Bonnet has argued that the eighteenth-century mirror did not just reflect the anxiety of social status but that the mirror was the cause for increased self-consciousness through a new awareness of the body. ${ }^{37}$ This idea recalls Elias's Civilizing Process or even Foucault's panopticon: that the knowledge of one's visibility, to know one is being observed, fundamentally changes behaviour. Even though some could use the mirror to their social advantage, this visibility also carried risk: the mirror increased the chance one might be seen in a moment of lapsed restraint. Mirrors in the interior thus had a two-part effect on behaviour. They increased power and control over one's appearance, by allowing access to one's image as another. However, at the same time, mirrors augmented one's consciousness of that appearance. Any internalized sense of this exposure was not imagined - in the rooms of polite society, the mirrors lining walls did mean that those around you could see you from many different angles. The mirror's ability to visually multiply ensures that if one is performing elite identity correctly, beautifully, and with leisure, this image is visually repeated and one's company can look upon you inconspicuously with approval.

As Meredith Martin and Katie Scott have noted about the intensification of strict rules of convenance and bienséance in eighteenthcentury architectural treatises, perhaps the increased interest in

35. Ibid., 113 .

36. The term 'dramaturgy,' originally meaning the study of dramatic composition, was adopted by sociologist Erving Goffman to describe how social interactions resemble theatrical acts and dialogue. See Goffman, The Presentation of the Self in Everyday Life (1959).

37. Melchior-Bonnet, The Mirror: A History,134. 
outlining behaviour in courtesy and etiquette manuals does not indicate a tightening of rules but signals an attempt to save something that was rapidly slipping away. ${ }^{38}$ The French aristocracy of the early-eighteenth century was in a precarious place. They were rich yet perpetually in debt. They were well-mannered yet at risk from appropriation of these manners from the bourgeoisie. ${ }^{39}$ Without political power at court, they could only hope to hold on to their position by appearances and aesthetic display. Thus, the rococo mirror was an important and innovative tool for private and public surveillance and created new opportunities for self-fashioning and control of social identity. In a time of the French nobility redefining itself in terms of manners and sociability, the rococo mirror was a vital instrument for both the creation and reinforcement of manners, all while providing visual pleasure and delight to its audiences.

To return to the elite shoppers in L'Enseigne de Gersaint, the pose of the women on the right appears relaxed; her form barely visible beneath the abundant folds of her pale pink dress. The tilt of her head, the drape of her arm, and the passive expression on her face all evoke leisure. However, the pose is almost too perfect to be truly effortless: every line of her body curves gracefully, and the yards of fabric fall just so. This perfection, of course, may be the result of Watteau's artistic intervention. Still, Watteau shows us the mirror, and the woman looking within it. This access to her image through mirrors presents the possibility that she is in control of her own posture and appearance. The other eyes attracted to the mirror's face, those of the men behind her, suggest that she is not the only one apprehending this reflection.

38. Martin, "The Ascendancy of the Interior in Eighteenth-Century Architectural Theory," in Architectural Space in Eighteenth-Century Europe, 24.

39. Auslander, Taste and Power: Furnishing Modern France, 59. 


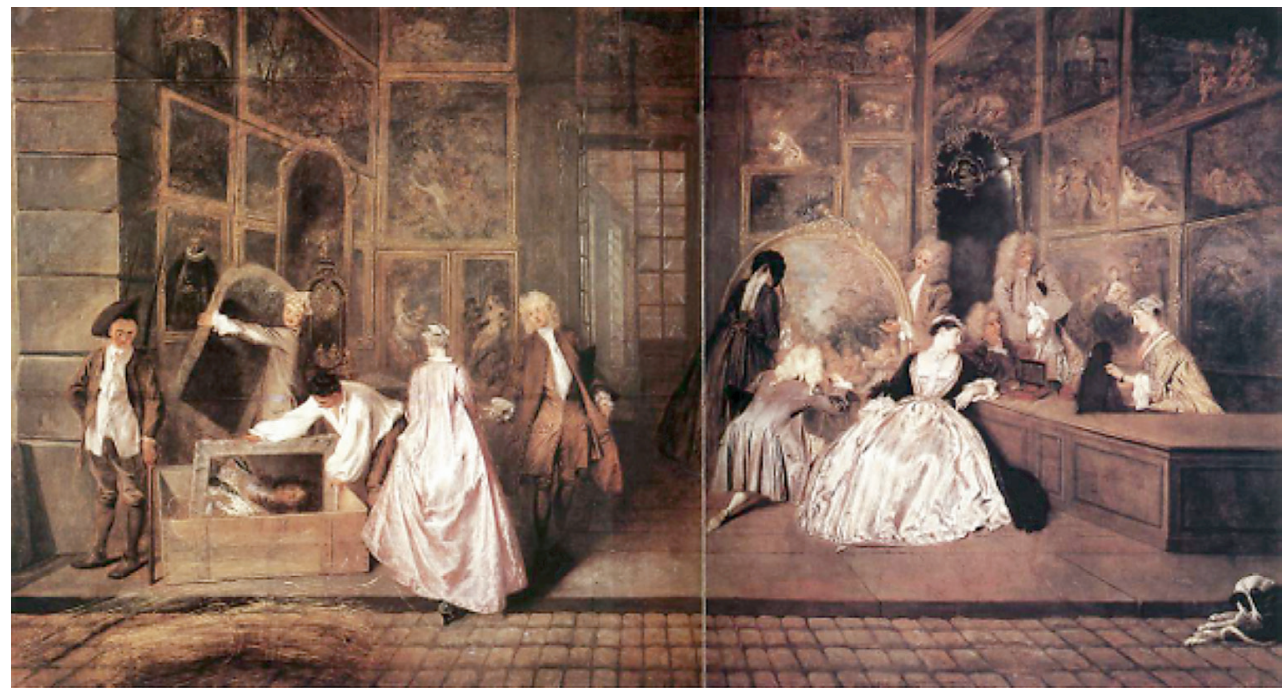

Figure 1. Jean-Antoine Watteau, L'Enseigne de Gersaint, 1720-21. Oil on canvas. $163 \mathrm{~cm} \times 308 \mathrm{~cm}$. Charlottenburg Palace, Berlin. Photograph: Wikimedia commons (public domain).

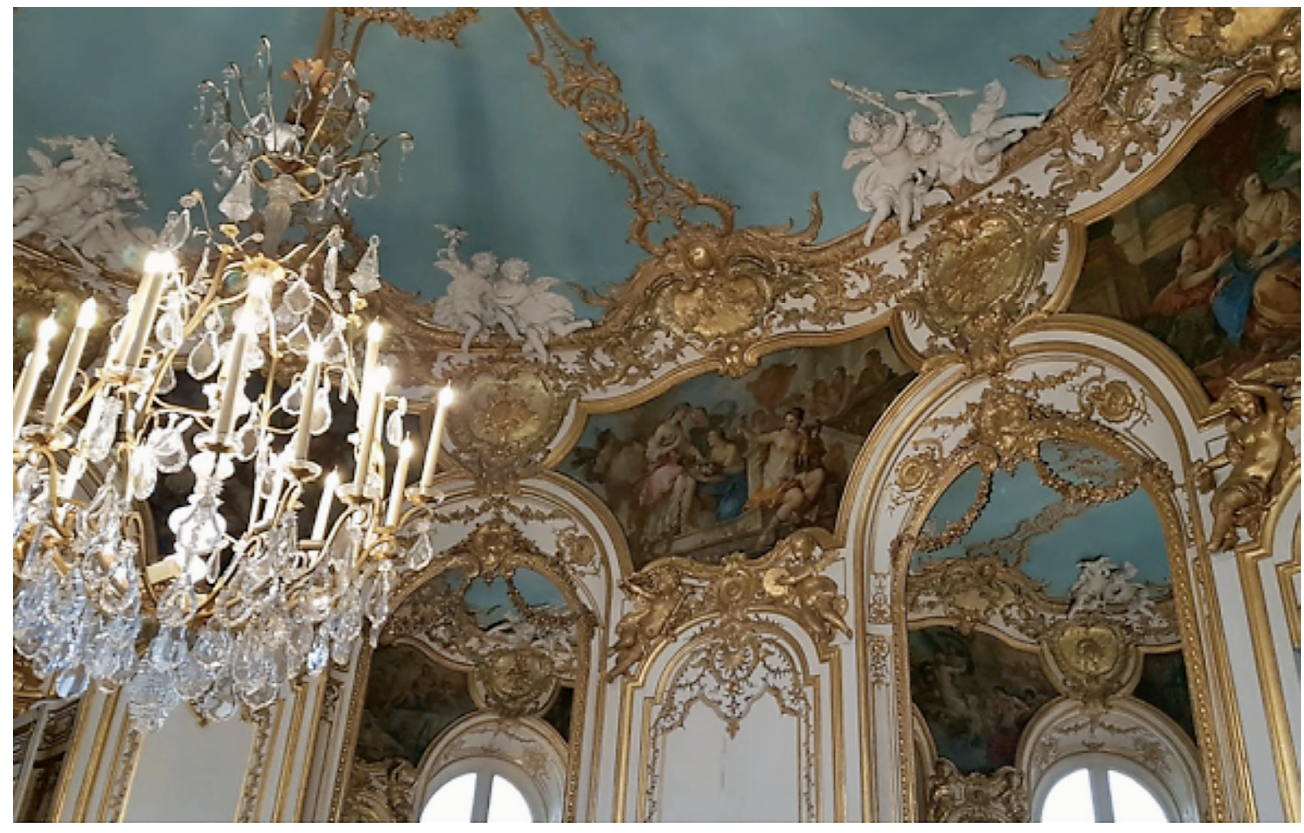

Figure 2. Germain Boffrand, Salon de la Princess at the Hôtel de Soubise, 1738-40. Paris. Photograph by author. 